\title{
The Impact of Inflation on the Automobile Sales in South Africa
}

\author{
Retius Chifurira \\ School of Mathematics, Statistics and Computer Sciences, University of KwaZulu - Natal, \\ Private Bag X54001 Durban 4000, South Africa \\ Email: chifurira@gmail.com \\ Innocent Mudhombo \\ Faculty of Management Sciences: Vaal University of Technology \\ Private Bag X021, Vanderbij/park, 1900, South Africa \\ Email: imudhombo@yahoo.com \\ Marian Chikobvu \\ Faculty of Management Sciences: Vaal University of Technology \\ Private Bag X021, Vanderbijlpark, 1900, South Africa \\ Email:marianc@vut.ac.za \\ Dorah Dubihlela \\ Faculty of Management Sciences: Vaal University of Technology \\ Private Bag X021, Vanderbijlpark, 1900, South Africa \\ Email:dorahd@vut.ac.za
}

\section{Doi:10.5901/mjss.2014.v5n7p200}

\section{Abstract}

This paper analyses the relationship between inflation (INF) and Automobile sales in South Africa by using the co-integration and causality tests. The analysis has been conducted using monthly data over the period 1960:1 through 2013:9. The Augmented Dickey-Fuller Unit Root test indicates that the two series are stationary in the first-difference not in level. The Johansen-Juselius co-integration test show that INF and new vehicle sales (NVS) are co-integrated in the long run, hence, long-run equilibrium exist between the two variables. This study, using the Granger-Causality test has found that there is oneway causal effect (unidirectional causality) running from INF to NVS at $5 \%$ level of significance. Given that the automotive industry contributes 6\% to the country's Gross Domestic Product (GDP) and creating more than 300000 jobs, South Africa must double its efforts in managing inflation at very low levels.

Keywords: Inflation, New Vehicle Sales, Co-integration, Causality test, South Africa.

\section{Introduction}

The impact of inflation on output and sales has been one of the most common concerns in macroeconomics (Ilter, 2012). It is commonplace that inflation poses serious economic hitches to businesses through its effect on the loss of consumer buying power, social instability and loss of confidence in the currency (Ashraf, Gershman \& Howitt, 2013). With its salient effects to both businesses and consumers, a deep understanding of its costs becomes indispensable. Koch and Bosch (2009) therefore refer to inflation as a cruel tax, possibly because it hurts the poor more than the rich and therefore seen as unfair.

Inflation is broadly defined as a rise in the general price level of goods and services in the economy without a corresponding rise in the value of those commodities. Makinen (2003) defines inflation as the sustainable and continuous rise in the general price level or a fall in the value of money. Inflation has salient effects in modern economies. There is an overall consent that high rates of inflation are not desirable in an economy, as supported by a substantial body of evidence indicating that sustained and predictable high rates of inflation can have adverse consequences in the economy's long-run rate of real growth and the level of economic activities (Ashraf, et al., 2013). Price stability, as defined 
in modern monetary theory and central banking practice is typically associated with a moderate rate of price inflation.

Whilst a diverse of empirical studies have concentrated on the effects of inflation on economic growth (Feldstein, 1997:125; Faria \& Carneiro, 2001:1; Olavarria-Gambi, 2003:1), another concerned with the welfare costs of inflation which includes poverty and consumption (Sothearith \& Sovannarith, 2008; Braun, 2008) and recently inflation targeting policy framework (Svensson, 2010; Thornton, 2012). There has been a dearth of research on the impact of inflation on automobile sales in South Africa. This study will then attempt to cover this gap.

\section{Review of Literature}

\subsection{South African inflation trend}

In South Africa, there has been three distinct monetary policy regimes targeting at inflation in South Africa since 1980 (Aron \& Muellbauer, 2007). The first period, from 1980 to 1989 was characterised by high inflation rates, ranging from 11.5 to $18.6 \%$ and averaging $14.7 \%$ during the period. During this period, the monetary policy failed to contain inflation. The second period, 1990 to 2000, saw inflation falling significantly in the early part of the 1990s to under 10\%, subsequently decreasing to $5.2 \%$ in 1999 and the third period is from 2000 to present where SARB is in pursuit of an official and clearly stated inflation target (Burger \& Marinkov, 2009).

Inflation in South Africa is monitored by the South African Reserve Bank (SARB) and is measured using the Consumer Price Index (CPI). From the period 2000 till present, the SARB pursues an official and clearly stated inflation target (Burger \& Marinkov, 2009). The objective of such monetary policy rests on the proposition that inflation is bad for economic growth, employment creation and distribution of income (Mboweni, 2004). Due to this, inflation is made top priority even though at the expense of other economic challenges such as unemployment. Butler (2010) poses that inflation targeting has been one of the most significant monetary policy reforms since 1994. At the beginning of the inflation targeting policy, the targets was set at 3-5\% However, an increase in the inflation rate in 2002 prompted the Minister of Finance to announce in October 2002 that the inflation target would be at 3-6\% (Aron \& Muellbauer, 2007), a band which is still in practice today. The SARB is making efforts to maintain this range, although inflation has in some years fallen outside the range especially during the period of global economic turmoil (Butler, 2010).

Inflation targeting is a monetary policy strategy aimed at maintaining price stability by focusing on deviations in published inflation forecasts from an announced inflation target (Svensson, 2009). The targeted inflation bands are publicly announced and any non-conformity from the target is noted. Monetary policy in South Africa is aimed at reducing inflation and improving the country's international competitiveness. Perturbing to policy makers is that the rate of inflation in South Africa remains above the rates of the country's main trading partners like Germany, Japan, the UK and the USA (Tshabalala \& Rankhumise, 2011). Contributing factors to this high rate of inflation include increase in wages which is more than the increase in productivity, imported inflation, the growth in money supply and an increase in aggregate demand (Akinboade Akinboade, Niedermeire, \& Siebritts, 2001).

\subsection{The automobile industry in South Africa}

Automobile ownership the world over has significantly increased in the past two decades (Shahabudin, 2009). South Africa has seen its car ownership increase from 6 million in 2000 to more than 10 million in 2013 (National Traffic Information System, 2014). Before the advent of democracy in 1994, private cars were only considered luxury transportation tools on the roads of South Africa. In today's life, the importance of owing a car is undebatable in South Africa and the rest of the world. According to Sean et al (2003) the need to purchase a personal car is considered the second priority after house ownership in the United States of America. In South Africa, the trend suggests that car ownership takes first priority than house ownership. Thus, owning a car is a status in the South African society.

Demand for automobiles significantly affects the travelling trends, tourism industry and the development of the transportation infrastructure in a country (Ebu Eisheh \& Mannering, 2002). South Africa has invested a lot of its resources on transportation infrastructure development from 2008. These activities contribute to economic expansion and creation of new employment. South Africa's automotive industry contributes at least $6 \%$ to the country's GDP and accounting for almost $12 \%$ of South Africa's manufacturing exports. The sector employs 28000 people directly in the automotive manufacturing, with 65000 employed in the component manufacturing industry and 200000 are employed in retail and aftermarket activities (Automotive Industry Export Council, 2010). The importance of the sector to the country's economic growth cannot be underestimated.

Based on OICA statistics, total production of automobiles in South Africa had increased tremendously at the rate of 
70\% for the last 13 years (1999-2013). Figure 1 illustrates the car production for South Africa from 1999 to 2012.

Figure 1. South Africa Car Production (1999-2012)

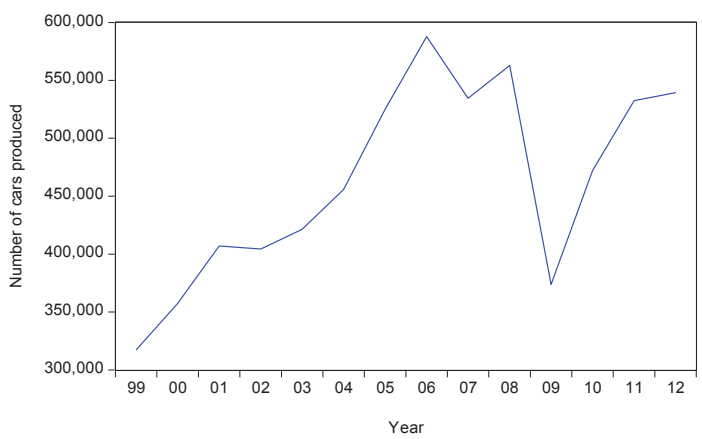

Source: OICA statistics

Figure 1 clearly shows that South Africa's car production has been steadily increasing from year to year serve for a downward trend between 2008 and 2010. The car production downward trend of 2008 to 2010 may have been partly caused by labour unrest, the world economic crisis and a rise in inflation. Inflation means a continuous increase in prices of goods and services. South Africa like any other developing country, faces a daunting task of managing inflation. The fundamental objective of macroeconomic policies in both the developed and developing countries is to sustain high economic growth with a very low inflation (Chimobi, 2010). Past research has confirmed relationship between car sales and macroeconomic variables (Mimovic, 2012; Sturgeon \& Van Biesebroeck, 2010; Sivak \& Tsimhoni, 2008; Hamilton, 1988; Lee \& Ni, 2002; Dargay \& Gately, 1998; Duncan, 1980; and Muhammand, Hussin \& Razak, 2012). Muhammand et al (2012) reveals the existence of causal correlation between macroeconomics variables such Gross Domestic Product (GDP), inflation, Unemployment and loan rate and car sales in the ASEAN countries. Dargay \& Gately (1998) projected the growth in car and total vehicle stock to the year 2015 for OECD countries. The projections were based on growth of the car per population ratio. Fuel hikes has been shown to impact negatively on car sales and sometimes influence car buyers to purchase smaller sized cars (Duncan, 1980 and Hamilton, 1988). Specific research on this subject on South Africa is scarce. This paper aims to investigate the relationship between inflation and automobile sales in South Africa.

This paper is organised as follows: section two present the research methodology followed by analysis of data in section three. Section four will put forth the empirical results and discussion. The final section of the paper, we discuss the implications and recommendations of this study.

\section{Methodology}

This study focuses on testing the causal relationship between New Vehicle Sales (NVS) and Inflation (INF) for South Africa. The monthly inflation data was obtained from South African Reserve Bank website and monthly new vehicle sales data from 1969 to 2013 was obtained from International Monetary Fund (IMF) website. All variables are transformed to natural logarithm form.

\subsection{Co-integration}

Regressions involving time series data include the possibility of obtaining spurious results unless there is an existence of a long - run equilibrium relationship between variables $X$ and $Y$ (Lean, 2008). The long - run relation is referred to as cointegration. According to Harris (1995) variables are co-integrated if both variables become stationary after differencing $d$ times. The series are said to be integrated of order $d$, denoted by $I(d)$. We then say the two series are co-integrated of order $(d-1)$, denoted by $I(d-1)$ (Enders, 2004). A stochastic process is process is stationary if the mean and variance are infinite for all time $t$ and $t-s$, and the covariance is time invariant. That is:

$$
\begin{aligned}
& E\left(Y_{t}\right)=E\left(Y_{t-s}\right)=\mu \\
& \operatorname{Var}\left(Y_{t}\right)=\operatorname{Var}\left(Y_{t-s}\right)=\sigma_{y}^{2} \\
& \text { and } \operatorname{Cov}\left(Y_{t}, Y_{t-s}\right)=\operatorname{Cov}\left(Y_{i-s}, Y_{i-t-s}\right)=\gamma_{s}
\end{aligned}
$$


where $\mu, \sigma_{y}^{2}$ and $\gamma_{s}$ are all constants.

A necessary precondition to co-integration test is to check stationarity at the same order of integration of the variables under consideration. A two-step approach is used in this study, we check for stationary of both variables at order zero $(I(0))$, at order one $(I(1))$ until both variables are stationary (Enders, 2004).

\subsection{Testing for Stationary}

The Augmented Dickey-Fuller (ADF) is one of the commonly used test for stationarity of time series. The test is also known as the unit root (non-stationary) test. There are three cases of the ADF test equation depending on the nature of the time series data to be tested.

a) When the time series is flat (no trend) and potentially slow-turning to zero. The test equation is:

$\Delta Z_{t}=\theta Z_{t-1}+\alpha_{1} \Delta Z_{t-1}+\alpha_{2} \Delta Z_{t-2}+\cdots+\alpha_{p} \Delta Z_{t-p}+\varepsilon_{t}$

The equation has no intercept and no time trend.

b) When the time series is flat (no trend) and potentially slow-turning to non-zero value. The test equation is:

$\Delta Z_{t}=\alpha_{0}+\theta Z_{t-1}+\alpha_{1} \Delta Z_{t-1}+\alpha_{2} \Delta Z_{t-2}+\cdots+\alpha_{p} \Delta Z_{t-p}+\varepsilon_{t}$

The equation has an intercept term $\left(\alpha_{0}\right)$ but no time trend.

c) When the time series has a trend in it (either up or down) and is potentially slow turning around a trend line you would draw through the data. The test equation is:

$\Delta Z_{t}=\alpha_{0}+\theta Z_{t-1}+\gamma t+\alpha_{1} \Delta Z_{t-1}+\alpha_{2} \Delta Z_{t-2}+\cdots+\alpha_{p} \Delta Z_{t-p}+\varepsilon_{t}$

The equation has an intercept term $\left(\alpha_{0}\right)$ and time trend $(\gamma t)$. In all cases $\varepsilon_{t}$ is a white noise error term

(Eviews 8 Manual).

According to Chomobi (2010) cited in Niyimbanira (2013) the ADF test relies on rejecting the null hypothesis of the data need to be differenced to make it stationary (the series is non-stationary) in favour of the alternative hypothesis of the data is stationary and does not need to be differenced.

\subsection{Testing for Co-integration}

To investigate the possible existence of a long-run equilibrium relationship between NVS and INF, the Johansen Juselius Full Information Maximum Likelihood (ML) technique is used (Johansen, 1988; Johansen \& Juselius, 1990). According to Kadir \& Jusoff (2010); Lean (2008) and Hallan \& Zanoli (1993), the Johansen - Juselius approach provides a more accurate estimate for the parameters of the long-run relationship. Just like the unit root test, there can be a constant term, trend term, both or neither in the model. If there is co-integration between two variables, there exists a long-run effect that prevents the two series from drifting away from each other. This will force the two series to converge into long-run equilibrium.

\subsection{Granger-Causality Test}

This study further explores the relationship between the series using the Granger - Causality test. If the series are found to be co-integrated then there must be Granger - causation in at least one direction (Granger, 1998). In the Granger Causality sense, $X$ having a causality effect on $Y$ means $X$ is a cause of $Y$, if it is useful in forecasting $Y_{1}$. Hansen \& Rand (2005) emphasised the importance of including the Error Correction Term (ECT) in the model if the two variables are co-integrated. The bivariate auto regression of the relationship between NVS and INF is:

$$
\begin{aligned}
& \Delta \ln N V S_{t}=\alpha_{0}+\sum_{i=1}^{n} \alpha_{1, t} \Delta \ln N V S_{t-1}+\sum_{i=1}^{m} \alpha_{2, t} \Delta \ln I N F_{t-1}+\delta_{1} E C T_{t-1}+\varepsilon_{1, t} \\
& \Delta \ln I N F_{t}=\beta_{0}+\sum_{i=1}^{n} \beta_{1, t} \Delta \ln I N F_{t-1}+\sum_{i=1}^{m} \beta_{2, t} \Delta \ln N V S_{t-1}+\delta_{2} E C T_{t-1}+\varepsilon_{1, t}
\end{aligned}
$$

Where $\alpha_{0}$ and $\beta_{0}$ denotes the deterministic component and $\varepsilon_{i, t}$ is white noise. ECT $T_{t-1}$ is the error correction term. The estimates of $\delta_{1}$ and $\delta_{2}$ can be interpreted as the speed of adjustments. As in Equation 1, INF is said to "Granger - cause" NVS, if the error correction term $E C T_{t-1}$ is different from zero even though the sum of the coefficients of lagged INF is insignificant. If co-integration between the two variables under study does not exist, the standard Granger - Causality approach can be employed without including the error correction term $\left(E C T_{t-1}\right)$ (Granger, 1969).

\section{Empirical Results and Discussion}

In this section results for tests of co-integration of INF and NVS are presented and discussed. 


\subsection{Inflation and New Vehicle Sales for South Africa}

Figure 2 shows the time series plot of the natural logarithm transformed INF and NVS data.

Figure 2. Time series plot of natural logarithm transformed Inflation and New Vehicle Sales data.

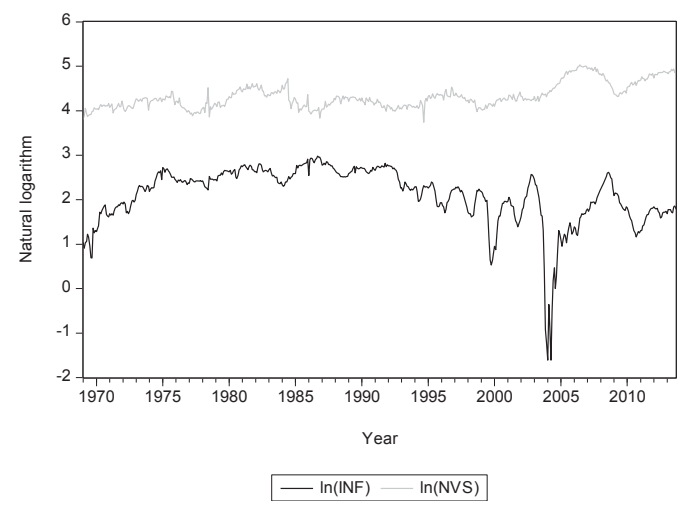

From Figure 2, it seems the NVS and INF series are both flat trending however, they seem to be are trending together is unison suggesting a possibility of long-run relationship.

\subsection{The Unit Root test}

It is important to check for stationarity of the variables before estimating the co-integration. We check for stationarity of the variables at their levels (zero order of integration). From Figure 1, the graph of NVS time series is flat (no trend) and potentially slow-turning to non-zero value. The ADF test equation is:

$\Delta N V S_{t}=\alpha_{0}+\theta N V S_{t-1}+\alpha_{1} \Delta N V S_{t-1}+\alpha_{2} \Delta N V S_{t-2}+\cdots+\alpha_{p} \Delta N V S_{t-p}+\varepsilon_{t}$

Table 1 shows the ADF test for natural logarithm transformed NVS data at zero order of integration.

Table 1. ADF test for natural logarithm NVS

\begin{tabular}{llc}
\hline \hline & & t-Statistic Prob. $^{*}$ \\
\hline \hline Augmented Dickey-Fuller test statistic & & 0.8027250 .8854 \\
\hline Test critical values: & 1\% level & -2.569308 \\
& $5 \%$ level & -1.941418 \\
& $10 \%$ level & -1.616300 \\
\hline \hline
\end{tabular}

The results from table 1 shows that the null hypothesis of non-stationary cannot be rejected. The estimated $t$-statistics is greater than the critical values at $1 \%, 5 \%$ and $10 \%$ level of significance. We can conclude that NVS is non stationary at integrated order zero, I (0).

We check for stationarity of the INF series at integrated order zero, I (0). From Figure 1, the INF time series plot seems to be flat (no trend) and potentially slow-turning to zero. The ADF test equation is:

$\Delta I N F_{t}=\theta I N F_{t-1}+\alpha_{1} \Delta I N F_{t-1}+\alpha_{2} \Delta I N F_{t-2}+\cdots+\alpha_{p} \Delta I N F_{t-p}+\varepsilon_{t}$

Table 2 shows the ADF test for natural logarithm transformed INF data at zero order of integration.

Table 2. ADF test for natural logarithm INF

\begin{tabular}{llll}
\hline \hline & & t-Statistic & Prob. $^{*}$ \\
\hline \hline Augmented Dickey-Fuller test statistic & & -0.770622 & 0.3822 \\
\hline Test critical values: & $1 \%$ level & -2.569341 & \\
& $5 \%$ level & -1.941423 & \\
& $10 \%$ level & -1.616297 & \\
\hline \hline
\end{tabular}

*MacKinnon (1996) one-sided p-values. 
The results from table 1 shows that the null hypothesis of non-stationary cannot be rejected. The estimated $t$-statistics is greater than the critical values at $1 \%, 5 \%$ and $10 \%$ level of significance. We can conclude that INF is non stationary at integrated order zero, I (0).

\subsection{Unit root test at first difference}

Having observed that the series are non-stationary at their levels we then check for stationary of transformed data at first level difference (one order of integration). Table 3 and 4 shows the results of ADF test on first level differenced NVS and INF data respectively.

Table 3. ADF test at First Difference (NVS)

\begin{tabular}{llll}
\hline \hline & & t-Statistic & Prob. $^{*}$ \\
\hline \hline Augmented Dickey-Fuller test statistic & & -17.88742 & 0.0000 \\
\hline Test critical values: & 1\% level & -2.569308 & \\
& 5\% level & -1.941418 & \\
& $10 \%$ level & -1.616300 & \\
\hline \hline
\end{tabular}

${ }^{{ }^{*} M a c K i n n o n ~(1996) ~ o n e-s i d e d ~ p-v a l u e s . ~}$

Table 4. ADF test at First Difference (INF)

\begin{tabular}{llll}
\hline \hline & & t-Statistic & Prob. $^{*}$ \\
\hline \hline Augmented Dickey-Fuller test statistic & & -9.096068 & 0.0000 \\
\hline Test critical values: & 1\% level & -2.569341 & \\
& 5\% level & -1.941423 & \\
& 10\% level & -1.616297 & \\
\hline \hline
\end{tabular}

*MacKinnon (1996) one-sided p-values.

The results from table 3 and 4 show that the null hypothesis of non-stationary is rejected, indicate that both NVS and INF are stationary at integrated order one, I (1). The estimated $t$-statistics are less than the critical values at the $1 \%, 5 \%$ and $10 \%$ levels of significance. This suggest that NVS and INF may be co-integrated at order zero.

\subsection{Testing for co-integration}

Having tested the stationarity of each time series we then search for co-integration between the two variables. This study employs the Johansen-Juselius ML co-integration test to investigate for long-run equilibrium relationship between NVS and INF. An optimum lag length for Vector Auto Regression (VAR) is required for the test. The selection strategy is to choose a lag length where the residuals of the VAR are normally distributed and white noise. Using a lag length of 12 months (one year), the findings for trace and maximum eigenvalue co-integration tests are reported in table 5 and 6 .

Table 5. Unrestricted Co-integration Rank Test (Trace)

\begin{tabular}{ccccc}
\hline \hline $\begin{array}{c}\text { Hypothesized } \\
\text { No. of CE(s) }\end{array}$ & Eigenvalue & $\begin{array}{c}\text { Trace } \\
\text { Statistic }\end{array}$ & $\begin{array}{c}0.05 \\
\text { Critical Value }\end{array}$ & ${\text { Prob. }{ }^{* *}}^{\text {None }{ }^{*}}$ \\
\hline \hline At most 1 & 0.036560 & 20.31392 & 12.32090 & 0.0019 \\
& 0.000938 & 0.499386 & 4.129906 & 0.5428 \\
\hline \hline $\begin{array}{l}\text { Trace test indicates 1 cointegrating eqn(s) at the 0.05 level } \\
\text { * denotes rejection of the hypothesis at the 0.05 level }\end{array}$ & & \\
**MacKinnon-Haug-Michelis (1999) p-values & &
\end{tabular}

Table 6. Unrestricted Co-integration Rank Test (Maximum Eigenvalue)

\begin{tabular}{ccccc}
\hline \hline $\begin{array}{c}\text { Hypothesized } \\
\text { No. of CE(s) }\end{array}$ & Eigenvalue & $\begin{array}{c}\text { Max-Eigen } \\
\text { Statistic }\end{array}$ & $\begin{array}{c}0.05 \\
\text { Critical Value }\end{array}$ & Prob. $^{* *}$ \\
\hline \hline None ${ }^{*}$ & 0.036560 & 19.81453 & 11.22480 & 0.0013 \\
At most 1 & 0.000938 & 0.499386 & 4.129906 & 0.5428 \\
\hline \hline
\end{tabular}

Max-eigenvalue test indicates 1 cointegrating eqn(s) at the 0.05 level

* denotes rejection of the hypothesis at the 0.05 level

**MacKinnon-Haug-Michelis (1999) p-values 
Basing on the results reported in table 5 and 6 , both the trace and maximum eigenvalue statistics reject the null hypothesis of no co-integration between the variables at $5 \%$ level of significance. These findings indicate that there is a long-run equilibrium relation between new vehicle sales and inflation in South Africa over the sample period. Since there is co-integration, the causality specification is estimated with error correction term (ECT).

\subsection{Vector Error Correction Model}

The error correction term test, according to Engle and Granger (1987) helps to estimate how the observed model drifts towards the long-run equilibrium. The error correction model is:

$\Delta \ln N V S_{t}=0.0244+0.0141 \Delta \ln I N F_{t}-0.0151 \hat{\mu}_{t-1}$

Where $\hat{\mu}_{t-1}$ is the lagged value of the error correction term $\left(E C T_{t}\right)$ from the preceding period. The negative coefficient of the error correction term indicate that the $\Delta E C T_{t}$ is negative to restore the equilibrium. These results show, 0.015 of the discrepancy in the NVS and INF in the previous month is eliminated this month. It also indicates that the short-run changes in the inflation are quickly reflected in the new vehicle sales.

\subsection{Granger - Causality Test Analysis}

In order to examine the causal relationship between inflation and new vehicle sales in South Africa as well as directions of the series, then we run the Granger causality test. The estimated VAR for Granger - causality analysis are reported in table 8. The null hypothesis of INF does not Granger-cause NVS is rejected at $5 \%$ level of significance. At the same level of significance, we fail to reject the null hypothesis of NVS does not Granger-cause INF. The results, therefore suggest a unidirectional Granger causality of NVS and INF in South Africa.

Table 8. Results of Standard Granger Causality test

\begin{tabular}{lccc}
\hline \hline Null Hypothesis: & Obs & F-Statistic & Prob. \\
\hline \hline LN_NVS_does not Granger Cause LN_INF_- & 535 & 0.17377 & 0.8405 \\
LN_INF_does not Granger Cause LN_NVS_- & & 3.97288 & 0.0194 \\
\hline \hline
\end{tabular}

\section{Implications of the Study and Recommendations}

This study attempts to investigate the long-term relationship between new vehicle sales and inflation in South Africa by using co-integration and causality tests. The empirical results show that there is a long-run relationship between new vehicle sales and inflation over the sample period of 1969 to 2013. The finding of the study indicate that there is a unidirectional causal effect (one-way causality) from inflation to new vehicle sales. The following are some important policy implications for South Africa in terms of inflation and new vehicle sales that can be drawn from the findings. The South African government must continue to monitor inflation since the type of inflation which exist in South Africa is costpush inflation. This is in line with the study by Niyimanira (2013). Future economic policy should focus more on new vehicle manufacturing, the sector has the potential to grow and generate employment and more earning to South Africa. This study recommend developing a new vehicle sale predictive model including other explanatory variables such as labour and household vulnerability index.

\section{References}

Abu-Eisheh, S. A., \& Mannering, F. L. (2002). Forecasting automobile demand for economics in transition: a dynamic simultaneous equation system approach, Transportation Planning and Technology, 25(4), 311-331.

Akinboade, O.A., Niedermeire, E.W. \& Siebritts, F. R. (2001). South African Inflation Dynamics: Implications for policy. Anniversary of the Economic Society of South Africa, Johannesburg 1-15.

Aron, J., \& Muellbauer, J. (2007). Review of Monetary Policy in South Africa since 1994 in Aron, J. \& G.lola Kingdon. (Guest Editors), Special issue on South African Economic Policy under Democracy. Journal of African Economies, 16 (5):705-744.

Ashraf, Q., Gershman, B., \& Howitt, P. (2013). How inflation affects macroeconomics performance: and agent-based computational investigation. Harvard: Harvard University.

Braun, J. V. (2008). Rising food prices. What should be done? Washington D.C.: International Food Policy Research Institute.

Burger, P., \& Marinkov, M. (2009). Inflation Targeting and Inflation Performance in South Africa. Bloemfontein: University of Free State.

Butler, A. (2010). Inflation targeting in South Africa. A promising start with a challenging future. Bloemfontein: University of the Free 
State.

Chimobi, O. P. (2010). Inflation and Economic Growth in Nigeria, Journal of Sustainable Development, 3(2), 159-166.

Dargay, J. M. \& Gately, D. (1999). Income's Effect on car and vehicle worldwide: 1960-2015, Transportation Research Part A, 33, 101138.

Duncan, R. S. (1980). The Effect of Gasoline Prices on Automobile Sales, The American Economist, 24(1), 62-66.

Enders, W. (2004). Applied Econometric Time Series. Second Edition, John Wiley \& Sons, Inc. River Street, Hoboken, New Jersey.

Faria, R. J. \& Carneiro. G.F. (2001). Does high inflation affect growth in the long run and short run. Sidney: School of finance and Economics University of technology.

Feldstein, M. (1997). The cost and benefits of going from low inflation to price stability. Cambridge: National Bureau of economic research.

Granger, C. W. J. (1969). Investigating Causal Relations by Econometric and Cross-Spectral Method, Econometrica, 37(3), 424-428.

Granger, C. W. J. (1988). Some Recent Developments in a Concepts of Causality, Journal of Econometrics, 39(1-2), $199-211$.

Hallam, D., \& Zanoli, R. (1993). Error Correction Models and Agriculture Supply Response. European Review of Agricultural Economics, 20(2), 151-166.

Hamilton, J. (1988). A Neoclassical Model of Unemployment and Business Cycle. Journal of Political Economy, 96, 593-617.

Hansen, H. \& Rand, J. (2005). On the Causal Links between FDI and Growth in Developing Countries, UNU-WIDER Research Paper No. 2005/31, Helsinki.

Ilter, C. (2012). Exploring the effects of inflation on financial statements through ratio analysis. International Journal of Business and Social Sciences. 3 (13). 154-162.

Johansen, S. (1988). Estimation and Hypothesis testing of Co-integration Vectors in Gaussian Vector Autoregressive Models, Econometrica, 59(6), 1551-1580.

Johansen, S., \& Juselius, K. (1990). Maximum Likelihood Estimation and Inference on Co- integration with Application to the Demand for Money, Oxford Bulletin of Economics and Statistics, 52(2), 169-210.

Kadir, N., \& Jusoff, K. (2010). The Cointegration and Causality Tests for Tourism and Trade in Malaysia, International Journal of Economics and Finance, 2(1), 138-143.

Koch, S. F. \& Bosch, A. (2009). Inflation and the household. Towards a measurement of the welfare costs of inflation. Pretoria: South African Central Bank.

Lean, H. H. (2008). The Impact of Foreign Direct Investment on the Growth of the Manufacturing Sector in Malaysia, International Applied Economic and Management letters, 1(1), 41-45.

Lee, K. \& Ni, S. (2002). On the dynamic of oil shocks: a study using industry level data, Journal of Monetary Economics, 49, 823-852.

Makinen, G. (2003). Inflation: Causes, costs and current status: New York: Economic Policy Division.

Mboweni, T. T. (2004). The monetary policy framework for South Africa. Pretoria: South African Reserve Bank.

Mimovic, P. (2012). Applications of Analytical Network Process in Forecasting Automobile Sales of Fiat 500 L, Economic Horizons, 14(3), 169-179.

Muhammad, F., Hussin, M. Y. M., \& Razak, A. A. (2012). Automobile Sales and Macroeconomic Variables: A Pooled Mean Group Analysis for ASEAN Countries, IOSR Journal of Business and Management, 2(1), 15-21.

Niyimbanira, F. (2013). An Econometric Evidence of the Interactions between Inflation and Economic Growth in South Africa, Mediterranean Journal of Social Science, 4(13), 219-225.

Olararria-Gambi. M. (2005). Poverty reduction in Chile. Has economic growth been enough? Chile: Carfax Publishing.

Sean, P., Hill. M. K., \& Swiecki, B. (2003). Economic Contribution of the Automotive Industry to the U.S Economy: An update, a report for the Alliance of Automobile Manufacturers, Center for Automotive Research (CAR), 1-47.

Shahabudin, S. (2009). Forecasting Automobile Sales, Management Research News, 32(7), 670- 682.

Sivak, M. \& Tsimhoni, O. (2008). Future Demand for New cars in Developing Countries: Going Beyond GDP and Population Size, Report No. UMTRI-2008-47 September 2008, The University of Michigan Transportation Research Institute, U.S.A, 1-16.

Sotherwaith, T., \& Sovannarith, S. (2009). Impact of hiked prices of food and basic commodities on poverty in Combodia: Empirical evidence from CBMS five villages. http://www.pepnet.org/fileadmin/medias/pdf/CBMS_country_proj_profiles/Cambodi a/Cambodia_Impacts_of_Rising_Prices_of_Food_and_Commodity_on_Poverty_in_Ca mbodia.pdf Date of access: 3 Feb. 2012.

Sturgeon, T. J., \& Van Biesebroeck, J. (2010). Effects of the crisis on the Automotive Industry in Developing Countries, Policy Research Working Paper 5330, The World Bank, 1-31.

Svensson, L. E. O. (2009). Inflation targeting. Frankfurt: Central Bank of Cyprus.

Svensson, L. E. O. 2010. Inflation targeting. Cambridge: National Bureau of Economic Research.

Thornton, D. L. (2012). How did we get to inflation targeting and where do we need to now? A perspective from the United States experience. Federal Reserve Bank of St. Loius Review. 94 (1) 65-81.

Tshabalala, D. B. \& Rankhumise, E. M. (2011). Journal of Management Policy and Practice, 12(1): 108-114. 